Full length article

\title{
Aroclor 1254 inhibits the chemiluminescence response of peritoneal cavity cells from sharpsnout sea bream (Diplodus puntazzo)
}

\author{
Mirella Vazzana a , Gabriele Reas a , Matteo Cammarata ${ }^{a}$, Vincenzo Arizza ${ }^{\text {a, c, *, }}$ \\ Vincenzo Ferrantelli ${ }^{\mathrm{b}}$, Nicolò Parrinello ${ }^{\mathrm{a}}$ \\ a Dip. STEBICEF, Università degli Studi di Palermo, Via Archirafi, 18, Palermo, Italy \\ b Istituto Zooprofilattico Sperimentale della Sicilia "A. Mirri", Via Rocco Dicillo, 4, Palermo, Italy \\ ${ }^{c}$ IEMEST - Istituto Euromediterraneo di Scienza e Tecnologia, Palermo, Italy
}

\section{A R T I C L E I N F O}

\section{Article history:}

Received 11 March 2014

Received in revised form

7 May 2014

Accepted 27 May 2014

Available online 16 June 2014

\section{Keywords:}

Diplodus puntazzo

Aroclor 1254

Chemiluminescence response

Respiratory burst

Peritoneal cavity cells

\begin{abstract}
A B S T R A C T
Chronic exposure to polychlorinated biphenyls (PCBs) affect the immune system of fish and could lead to a decreased disease resistance. The effects of Aroclor 1254, PCB mixtures, on the Diplodus puntazzo innate immunity were examined by assaying the zymosan stimulated chemiluminescence response $(\mathrm{CL})$ of peritoneal cavity cells (PCCs) at various times $(1,24,48 \mathrm{~h}$ and $1-4$ weeks) from intraperitoneal injection of the xenobiotic ( $1 \mathrm{mg} \mathrm{kg}^{-1}$ body weight). Controls were performed by assaying cells from mediumtreated fish. Since the kinetic of the chemiluminescence response showed the highest peak at 25 min after the zymosan stimulation of the cells, the values found at that time were considered. The CL enhancement observed at $1 \mathrm{~h}$ after the treatment with xenobiotic was followed by a decreased response at $24 \mathrm{~h}$ and appeared to be lower at 1-4 weeks when compared to the CL response of the control, suggesting a protracted effect of PCBs on the peritoneal cavity. Since PCCs incubated in vitro for $1 \mathrm{~h}$ with 0.05 and $0.1 \mu \mathrm{g} \mathrm{ml}^{-1}$ Aroclor showed an enhanced CL, the effect of the xenobiotic could be exerted on the cell responsiveness to zymosan. It is known that fish CL response of PCCs can be imputed to phagocyte (macrophages and neutrophils) activation, these cells and their responsiveness to zymosan can be used in immunotoxicology assay to monitor the fish health in polluted environment.
\end{abstract}

(C) 2014 Elsevier Ltd. All rights reserved.

\section{Introduction}

Aroclor 1254 is one of several congeners present in the mixture of commercial polychlorinated biphenyls (PCBs) manufactured for several industrial purposes until banned in the late 1970s [1]. Nevertheless it has been estimated that approximately $10 \%$ of the PCBs ever produced are still environmentally available [2]. The high environmental persistence of this product, its ability to be bioaccumulated and its bio-magnification in the food chain renders it a biological risk [3,4].

Although the cessation of $\mathrm{PCB}$ production, congeners remain widely distributed in aquatic systems where they are released by slow desorption from sediments causing harmful biological effects on aquatic species being absorbed through epidermis, gills and contaminated food $[5,6]$. Despite they are ubiquitous aquatic contaminants, some toxicological effects of PCBs have been

\footnotetext{
* Corresponding author. Dip. STEBICEF, Università degli Studi di Palermo, Via Archirafi, 18, Palermo, Italy. Tel.: +39 09123891804.

E-mail address: vincenzo.arizza@unipa.it (V. Arizza).
}

underestimated [7] and little information is available regarding the impact of PCBs on fish innate immune system [8]. On the other hand, it has been shown that exposure to PCB congeners depress both humoral and cell mediated immune responses in mammalian host [9-11].

Phagocytosis is a main barrier of the innate immune system to contrast pathogens, and phagocyte sensitivity to xenobiotics can affect fish healthy.

Phagocytic cells are widely distributed in tissues of fish immune system [12-14], and they show morphological characters of mammalian neutrophils and macrophages [15,16] including an enhanced respiratory burst after activation [16]. Following a challenge, phagocytes increase their oxygen consumption and reactive oxygen intermediates (ROIs) can be measured using the chemiluminescence $(\mathrm{CL})$ assay.

In brief, a specific luminescence is amplified when luminol permeates cells and reacts with a variety of ROIs including superoxide, hydroxyl peroxide, singlet oxygen, etc. [17,18]. Xenobiotics can affect these cells and phagocyte respiratory burst appears to be especially sensitive to their effect [19]. 
Fish peritoneal cavity cells (PCCs) have been characterized morphologically [20] as macrophages, neutrophils, eosinophils and lymphocytes. In sea bass, the peritoneal neutrophils and macrophages are phagocytes [21], and in rainbow trout they are activated following injection of inflammatory agents [22,23]. PPCs can be recruited by intraperitoneal injection of an isosmotic medium, stimulated in vitro with zymosan, and their respiratory burst response evaluated by the CL assay [21].

In the present paper we report the effect of intraperitoneal exposure to a non-lethal concentration of Aroclor 1254 injected into peritoneal cavity of sharpsnout sea bass Diplodus puntazzo. At first, the kinetic of CL response of PPCs after zymosan challenge was displayed, then, the $\mathrm{CL}$ response as an effect of the xenobiotic was evaluated after in vivo or in vitro treatments. The PCB doses we used had no effect upon fish survival as well as on cell vitality up to the end of the experiments.

\section{Materials and methods}

\subsection{Fish}

Fish weighing 250-300 g were obtained from a fish farm (Ecoittica, TP, Italy), maintained with re-circulating water $\left(0.4 \mathrm{~L} \mathrm{~min}^{-1}\right)$ at $17 \pm 2{ }^{\circ} \mathrm{C}$. Fishes, in the department aquaria, were randomly separated into four fibre-glass tanks (1000 L, 21 fish each) and acclimated at constant environmental conditions for at least 2 weeks, and fed with commercial pellets (Trouvit, Hendrix $\mathrm{SpA}$ ). Feeding, lighting, water temperature and acclimation to housing were controlled. All experiments were performed in full compliance with the national rules and guidelines (D. Lgs 116/92 and subsequent amendments) and international European Commission Recommendation guidelines for the accommodation and care of animals used for experimental and other scientific purposes (2007/526/EC).

\section{2. $P C B$ in vivo exposures}

A stock Aroclor 1254 (PCB, Ultra Scientific) solution was prepared in dimetilsulfoxide (1 $\mathrm{mg}$ in $1 \mathrm{ml}$ DMSO) and diluted 1:4 with Hanks balanced salt solution (HBSS: $\mathrm{NaCl} 190 \mathrm{mM}, \mathrm{KCl} 5.36 \mathrm{mM}$, glucose $5.54 \mathrm{mM}, \mathrm{KH}_{2} \mathrm{PO}_{4} 0.44 \mathrm{mM}, \mathrm{Na}_{2} \mathrm{HPO}_{4} 0.56 \mathrm{mM}$; pH 7.6, $370 \mathrm{mOsm} \mathrm{kg} \mathrm{kg}^{-1}$ ). After anaesthesia with $0.05 \%$ 3-aminobenzoic acid ethyl ester methanesulfonate (MS222, Sigma-Aldrich, Germany) in sea water, the ventral surface of fish were disinfected with $70 \%$ ethyl alcohol and a volume $(1 \mathrm{ml})$ of xenobiotic solution (HBSSDMSO-PCB) containing $250 \mu \mathrm{g}$ PCB ( $1 \mathrm{mg} \mathrm{kg}^{-1}$ body weight) were injected into the peritoneal cavity of fish (IP: intraperitoneal injection) of tank 1 .

Fish from the tank 2 were injected with a same volume of HBSSDMSO, and the fish from tank 3 were injected with HBSS. Peritoneal cavity cells were collected after 1, 24, $48 \mathrm{~h}$ and 1, 2, 3 e 4 weeks. For each time, three distinct experiments were carried out and 189 fish in total were examined.

Fish $(n=3)$ from tank 4 were not treated and were used for in vitro experiments.

\subsection{Preparation of peritoneal cavity cells (PCCs)}

After each fish treatment the PCCs were harvested according [21], $10 \mathrm{ml}$ of isotonic (370 mOsm kg-1) Leibovitz medium (Leibovitz L15 medium containing $2 \%$ foetal calf serum, 100 units penicillin $\mathrm{ml}^{-1}, 100$ units streptomycin $\mathrm{ml}^{-1}$ and 10 units heparin $\mathrm{ml}^{-1}$ ) were injected into the peritoneal cavity. After massaging the ventral surface for $10 \mathrm{~min}$, the medium containing the PCCs was withdrawn with a syringe. The cells were collected by centrifuging at $400 \mathrm{~g}$ for $10 \mathrm{~min}$ at $4{ }^{\circ} \mathrm{C}$, counted in a haemocytometer and evaluated for cell mortality by Trypan blue exclusion test $(0.01 \%$ in Leibovitz medium). The cell number was

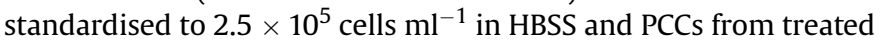
and untreated fish assayed for their $\mathrm{CL}$ response.

Differential counts of PPCs from three fish for each treatment were carried. Cell smears were performed on glass slide, stained with May Grunwald-Giemsa solution, and 100 microscopical fields $\left(2.6 \times 10^{3}\right.$ cells in total) were examined under a light microscope DLMB Leica, (Wetzlar, D). Data were reported as percent \pm SD.

\subsection{ROI measurement by a chemiluminescence assay $(C L)$}

The response of a constant number of PPCs $\left(2.5 \times 10^{5}\right.$ cells ml $^{-1}$ in HBSS) was measured as ROI production using a luminolamplified CL assay. Luminol solution was prepared as a potassium salt by adding $0.014 \mathrm{~g}$ luminol, $0.78 \mathrm{~g}$ potassium hydroxide and $0.618 \mathrm{~g}$ boric acid to $10 \mathrm{ml}$ of distilled water and bringing to $100 \mathrm{ml}$ by the addition of HBSS. This stock solution was stored in the dark and diluted 1:100 in HBSS to give a working luminol solution. Zymosan ( $\beta$-glucan of yeast cell wall, Sigma) was boiled for $30 \mathrm{~min}$ in phosphate buffered saline (PBS) and then centrifuged for $5 \mathrm{~min}$ at $400 \times \mathrm{g}$, suspended in $50 \mathrm{ml}$ of PBS and stored until use with a maximum storage time of 2 weeks [18]. The final concentration of zymosan was $1 \mathrm{mg} \mathrm{ml}^{-1}$.

Aliquots of $0.5 \mathrm{ml}$ PCC suspension $\left(1.125 \times 10^{5}\right.$ cells in HBSS $)$ were mixed with $0.5 \mathrm{ml}$ of the luminol solution in propylene vials. Cell response was displayed after adding $0.5 \mathrm{ml}$ of zymosan. Controls were performed as samples of the reaction mixture in which, in turn, luminol, zymosan or cells were substituted by medium.

A scintillation counter (Beckman LS 1800) was used to measure the CL. Data are expressed as counts per minute (cpm).

\section{5. $P C B$ in vitro exposures}

A PCC suspension $\left(2.5 \times 10^{5}\right.$ cells $\left.\mathrm{ml}^{-1}\right)$ was exposed according to Hammond [24]. From three untreated fish was incubated (v/v) with 0.05 or $0.1 \mu \mathrm{g} \mathrm{ml}^{-1}$ Aroclor in $\mathrm{H}-\mathrm{D}$, for $1 \mathrm{~h}$ at $18{ }^{\circ} \mathrm{C}$, and then assayed for their CL response. Cells incubated with HBSS or H-D were the controls. The experiments were performed in triplicate.

\subsection{Statistical analysis}

Data, in vivo, obtained from each fish group were presented as mean \pm SD of three distinct experiments in which were used 3 fish for each experiment, and statistically analysed by the Student's $t$ test. Differences were considered statistically significant for $P<0.05$. Data, in vitro, are the mean of three distinct experiments in which were used 3 fish for each experiment.

\section{Results}

\subsection{Effect of IP injection of Aroclor 1254 on fish survival}

The treatment with HBSS, H-D or H-D-PCB had no effect on behaviour, feeding and fish survival up to 4 weeks post injection and the cell mortality, evaluated by the Trypan blue exclusion test, was unchanged $(<1 \%)$.

\subsection{Kinetic of CL response of PCCs from fish inoculated with HBSS or $P C B$}

PCCs were withdrawn from fish treated for $1 \mathrm{~h}$ and were incubated with zymosan and CL measured at 5 min interval up to 60 min (Fig. 1). the PCCs from HBSS treated fish showed a CL values 


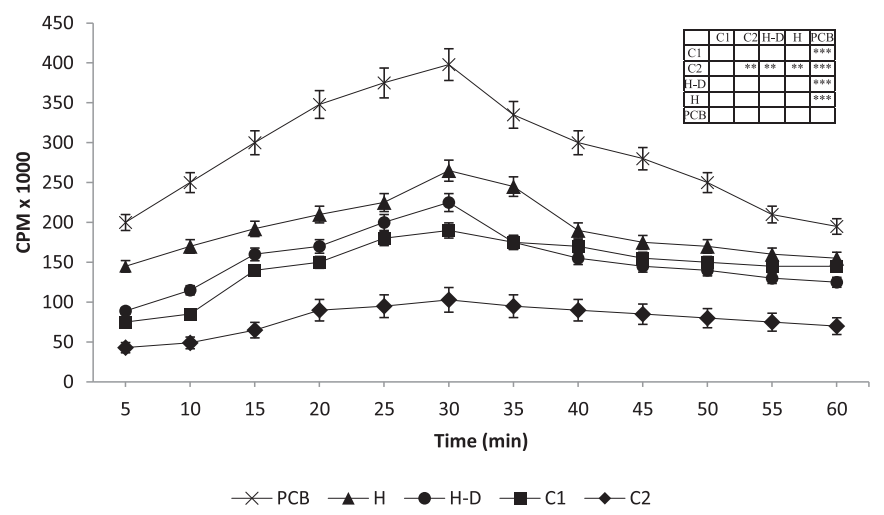

Fig. 1. Chemiluminescence response of PCCs at the same cellular number $\left(2.5 \times 10^{5} \mathrm{ml}^{-1}\right)$ activated by zymosan after intraperitoneal injection of HBSS $-\boldsymbol{\Delta}-(\mathrm{H})$, H-D - - (H-D), H-D-PCB $-\times-($ PCB), for $1 \mathrm{~h}$. Control = PCCs from untreated animals with- - (C1), and without- - (C2) zymosan. In table are shown the significance values between the various tests; ${ }^{* *}=p<0.01 ;^{* * *}=p<0.001$.

peaked $(220 \pm 20 \mathrm{cpm})$ at $30 \mathrm{~min}$ incubation time, then decreased and reached the initial level at $30 \mathrm{~min}$, whereas in the absence of zymosan the cells did not display any significant $\mathrm{CL}$ increase until $60 \mathrm{~min}$.

The cells harvested from fish treated with H-D injection, showed a kinetic of CL response similar to the above reported profile and peaked at $30 \mathrm{~min}$ reaching a value of $195 \pm 18 \mathrm{cpm}$ (Fig. 1). The PCB effect was shown by the significantly $(P<0.001)$ higher $C L$ response compared to that due to HBSS or H-D injection (Fig. 1). As shown in Fig. 1, PPCs collected from fish at $1 \mathrm{~h}$ treated fish with H-D-PCB yielded a typical profile but were more sensitive to the zymosan activation and their $\mathrm{CL}$ response resulted further amplified. The $\mathrm{CL}$ at $30 \mathrm{~min}$ was doubled $(400 \pm 80 \mathrm{cpm})$ compared to that of PCCs from HBSS fish. The treatment with HBSS containing DMSO did not cause any significant variation in the CL response, and it was at a level similar to that displayed by HBSS injection.

\subsection{Effects of $H-D$ or $P C B-H D$ on $C L$ response at various times post injection}

Based on the kinetic of the CL response, the values as follows reported were those found at $30 \mathrm{~min}$. Fig. 2 shows the activity of PCCs $\left(2.5 \times 10^{5}\right.$ cells $\left.\mathrm{ml}^{-1}\right)$ at various times after the H-D-PCB treatment ( $250 \mu \mathrm{g} /$ fish) or H-D alone. The effect of H-D treatment enhanced the CL activity of PCCs, and such an enhancement was

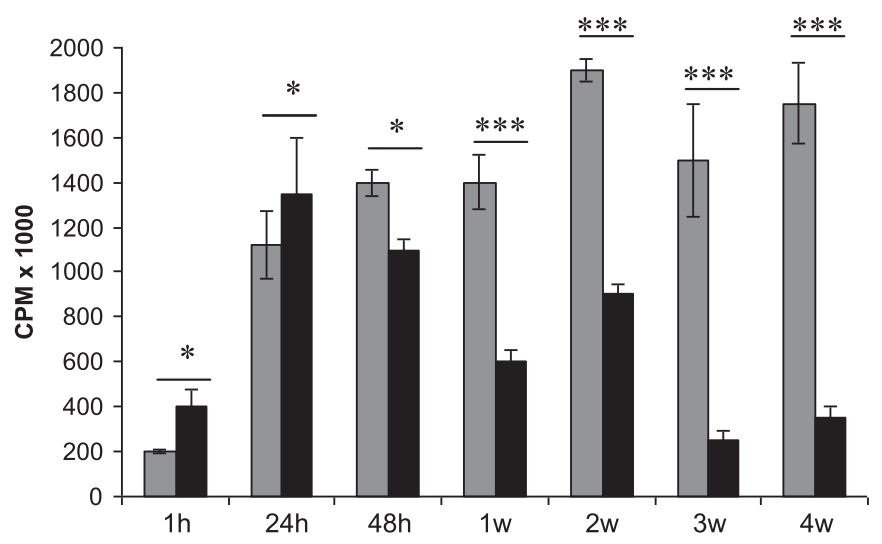

Fig. 2. A costant number $\left(2.5 \times 105 \mathrm{ml}^{-1}\right)$ of cells from the peritoneal cavity, assayed for CL response after treatment with HBSS + DMSO ( $\square$ ) and HBSS + DMSO-PCB ( $\mathbf{\square})$ at different times $\left(1,24,48 \mathrm{~h}, 1,2,3\right.$ and 4 weeks). ${ }^{*}=p<0.05$; $^{* * *}=p<0.001$.

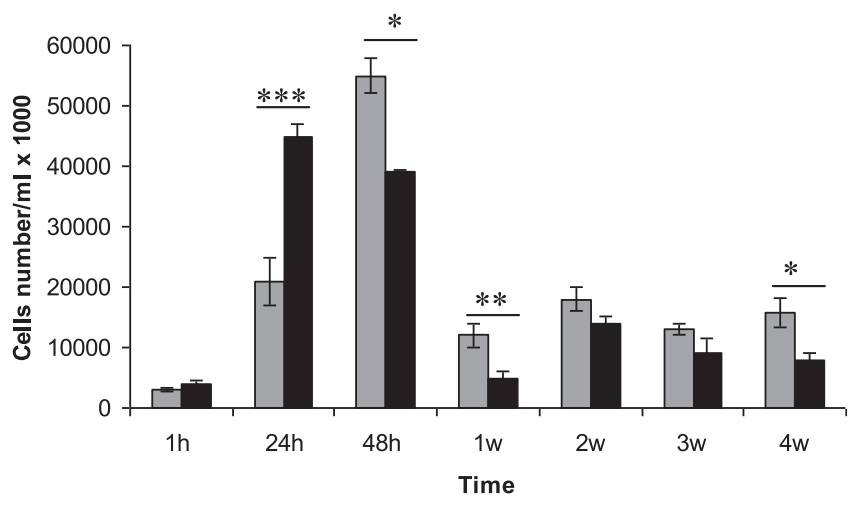

Fig. 3. Number of cells from peritoneal cavity after treatment with HBSS + DMSO ( $\square 1$ or HBSS + DMSO-PCB ( $)$ at different times (1, 24, 48 h, 1, 2, 3 and 4 weeks). ${ }^{*}=p<0.05$; $^{* *}=p<0.01 ;{ }^{* * *}=p<0.001$.

protracted until the end of the experiment as shown by the high CL level found at $48 \mathrm{~h}$ and at $1-4$ weeks (Fig. 2). When the effect of $\mathrm{H}-$ D was compared to that of the PCCs from fish treated with H-D-PCB, a CL enhancing effect of PCB was manifest at $1 \mathrm{~h}$ and $24 \mathrm{~h}$, then it decreased becoming significantly inhibitory $(P<0.05)$ at $48 \mathrm{~h}$. Such an inhibitory effect was more intense at 1 and 2 weeks $(P<0.001)$ and it was drastic at 3 and 4 weeks when the CL response was at the level found after $1 \mathrm{~h}$.

\subsection{PCB, HBSS and HBSS-DMSO exert a recruitment effect on PCCS}

To examine the effect of the medium or PCB on cell recruitment into the peritoneal cavity, the PPCs were collected at various times post treatment and counted. The H-D medium exerted an inflammatory effect as shown by the high cell number in the peritoneal cavity (Fig. 3 ). At $1 \mathrm{~h}$, the cell number $\left(3 \times 10^{6} \mathrm{ml}^{-1}\right)$ did not vary between $\mathrm{H}-\mathrm{D}$ and H/D-PCB treatments, whereas an increased amount of cells were recruited at $24 \mathrm{~h}\left(21 \times 10^{6} \mathrm{ml}^{-1}\right)$ reaching the highest value $\left(55 \times 10^{6} \pm 3 \times 10^{3} \mathrm{ml}^{-1}\right)$ at $48 \mathrm{~h}$ as an effect of the treatment, then decreased $\left(12 \times 10^{6} \pm 2 \times 10^{3} \mathrm{ml}^{-1}\right)$ at $1-4$ weeks even if higher levels were found compared with the cell counts accomplished at $1 \mathrm{~h}$ post injection $\left(3 \times 10^{6} \pm 3 \times 10^{2} \mathrm{ml}^{-1}\right)$.

After $1 \mathrm{~h}$ treatment with $\mathrm{H}-\mathrm{D}-\mathrm{PCB}$, the cell number did not change significantly $\left(4 \times 10^{6} \pm 4 \times 10^{2} \mathrm{ml}^{-1}\right)$ compared to the H-D injection, whereas it increased $(P<0.001)$ at $24 \mathrm{~h}$ $\left(45 \times 10^{6} \pm 2 \times 10^{3} \mathrm{ml}^{-1}\right)$. However, at $48 \mathrm{~h}$ the xenobiotic was less effective than $\mathrm{H}-\mathrm{D}$ in recruiting cells $\left(39 \times 10^{6} \pm 5 \times 10^{2} \mathrm{ml}^{-1}\right)$, and from 1 to 4 weeks the cell number lowered showing values $\left(5 \times 10^{6} \pm 1 \times 10^{3} \mathrm{ml}^{-1}\right)$ inferior than those observed as an effect of H-D injection.

As reported in Table 1, differential count of PPCs from untreated fish $(n=3)$ showed the following cell type proportions: $27.5 \% \pm 1.3 \%$ neutrophils, $12.2 \% \pm 1.7 \%$ eosinophils, $36.7 \% \pm 1.9 \%$ macrophages, and $23.4 \% \pm 1.5 \%$ lymphocytes. The cell recruitment

Table 1

Differential cells count of PCCs from untreated (HBSS, H-D) and PCB treated D. puntazzo specimens.

\begin{tabular}{llll}
\hline \multirow{2}{*}{ Cell type } & \multicolumn{2}{l}{ Number of cell $(\%)$} & \\
\cline { 2 - 4 } & HBSS & H-D & H-D-PCB \\
\hline Neutrophils & $27.6 \pm 1.3$ & $32.8 \pm 2.2$ & $17.0 \pm 1.1^{\text {a }}$ \\
Eosinophils & $12.2 \pm 1.7$ & $13.0 \pm 1.2$ & $17.8 \pm 2.3$ \\
Macrophages & $36.8 \pm 1.9$ & $38.5 \pm 1.5$ & $43.7 \pm 1.8$ \\
Lymphocytes & $23.4 \pm 1.5$ & $15.7 \pm 2.1$ & $21.5 \pm 2.7$ \\
\hline
\end{tabular}

$\mathrm{a}=P<0.001$ 
at 24 and $48 \mathrm{~h}$ due to H-D injection did not concern the relative proportion of a particular cell type $(32.8 \pm 2.2 \%$ neutrophils, $13.0 \pm 1.2 \%$ eosinophils, $38.5 \pm 1.5 \%$ macrophages, $15.7 \pm 2.1 \%$ lymphocytes) (Table 1), whereas H-D-PCB almost halved $(P<0.001)$ the neutrophil proportion $(17.0 \pm 1.1 \%)$.

\subsection{In vitro effect of $P C B$ s on peritoneal cavity cells}

To ascertain if the PCB affected the cellular pathway leading to the ROI production, $2.5 \times 10^{5} \mathrm{PCCs} \mathrm{ml}^{-1}$ from untreated fish were assayed in vitro in the presence of HBSS, H-D or H-D-PCB $\left(0.05-0.1 \mu \mathrm{g} \mathrm{ml}^{-1}\right)$ for $1 \mathrm{~h}$ and then stimulated with zymosan. The cell mortality after in vitro different treatments was inferior than $1 \%$.

Although different levels were found, the CL response to zymosan showed a typical kinetic profile like that displayed by PCCs from inoculated fish and the CL peaked at 25 min (Fig. 4). Likewise the effect exerted by in vivo treatment, HBSS and H-D amplified the $\mathrm{CL}$ response, but the levels they reached were lower than those showed by PCB-treated cells. When the cells were maintained in the presence of $0.1 \mu \mathrm{g} \mathrm{ml}^{-1}$ PCBs the $\mathrm{CL}$ response was significantly higher than that displayed by cells treated with $0.05 \mu \mathrm{g} \mathrm{ml}^{-1}$ PCBs, HBSS or H-D (Fig. 4).

\section{Discussion}

The polychlorinated biphenyls mixture, Aroclor 1254, is environmentally relevant since the congener composition of this mixture is very similar to that bio-accumulated in contaminated fish in the wild [25-27]. A broad spectrum of biological effects, including immunotoxicity, with specific modes of action has been associated with PCB congener mixtures [4,28-30].

The cells obtained from the peritoneal cavity following injection of a physiological medium, represents an useful model for studying the effects of xenobiotics on phagocytes. Likewise in mouse [31], PPCs can be used in toxicological assay and their phagocytic function is useful to evaluate and monitor the innate immune response of fish exposed to xenobiotic. In accordance with these assumptions, we used the peritoneal cavity cells of the sharpsnout sea bream $D$. puntazzo for examining Aroclor 1254 effect on phagocytes.

In a previous paper, we showed that the injection of an isosmotic medium into the sea bass peritoneal cavity caused a prompt influx of cell populations containing high proportion of neutrophils and macrophages [21]. This proportion was significantly higher than that obtained by examining cells separated from blood or

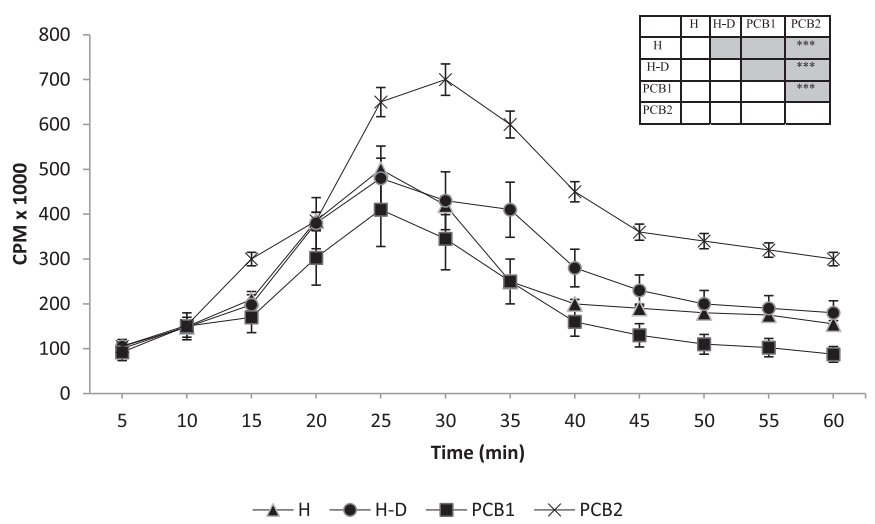

Fig. 4. Peritoneal cavity cells $\left(2.5 \times 10^{5} \mathrm{ml}^{-1}\right)$ stimulated by zymosan after treatment in vitro for $1 \mathrm{~h}$ with HBSS $--(\mathrm{H})$; HBSS-DMSO $-\mathbf{-}-(\mathrm{H}-\mathrm{D})$; HBSS-DMSO-PCB $0.05 \mu \mathrm{g} \mathrm{ml}^{-1}-\mathbf{-}-\left(\right.$ PCB1) and H-D-PCB $0.1 \mu \mathrm{g} \mathrm{ml}^{-1}-\mathbf{\Delta}-$ (PCB2). In table are shown the significance values between the various tests; ${ }^{* * *}=p<0.001$. organs of the immune system. Furthermore, we showed that in vitro cell challenge with zymosan enhanced the respiratory burst of peritoneal cavity phagocytes (macrophages and neutrophils) measured as chemiluminescence response. Such an enhancement was higher than that observed by assaying cells from the other tissues.

In this study we show that concentration of PCB, similar to that used for other study [24], are able to modulate the CL response of PPCs. Indeed, the kinetic of CL by PPCs from untreated sharpsnout sea bream (cells collected at 10 min after medium injection) and treated fish (cells collected with the standard method at various time after a PCB intraperitoneal injection) presented a CL profile similar to that reported in sea bass [21]. Just after the cells were incubated with zymosan the CL peaked at 25 min and decreased up to the initial value at $45 \mathrm{~min}$, whereas in the absence of zymosan not significant increase was observed. At 1 and $24 \mathrm{~h}$ after the PCB (dissolved in HBSS containing DMSO) was injected, PPCs became more sensitive to zymosan activation and their $C L$ response appeared to be significantly $(P<0.05$ and $P<0.05$ respectively) amplified. Since each assay was performed with a standard cell number and the cell mortality did not vary after the treatments, the increased respiratory burst of stimulated cells could be imputed to their enhanced reactivity.

A similar PCB stimulating effect on the phagocytic function was found by Lacroix [32] by assaying American place macrophages.

To ascertain if the CL amplifying effect of PCBs was due to an enhanced cell activity, PCCs from untreated fish were stimulated in vitro with zymosan after $1 \mathrm{~h}$ incubation with $0.05-0.1 \mu \mathrm{g} \mathrm{ml}$ PCB in HBSS-DMSO. This treatment did not cause increased cell mortality. Results showed that the CL profiles (within $60 \mathrm{~min}$ ) were similar including those obtained by assaying the PPCs from fish challenged in vivo. CL values reached the highest levels at $25 \mathrm{~min}$ in the presence of $\mathrm{PCB}$, whereas the CL values recorded for both untreated cells and HBSS-DMSO treated cells were significantly lower. When the CL response of PCCs from fish injected with Aroclor 1254 were examined at subsequent times and compared with that of the $\mathrm{H}-\mathrm{D}$ inoculation, the inhibitory effect of the xenobiotic could be observed at $48 \mathrm{~h}$ and at $1-4$ weeks.

It is noteworthy that both HBSS and HBSS containing DMSO injected into the peritoneal cavity $24-48 \mathrm{~h}$ or $1-4$ weeks exerted an inflammatory action. An increased number of PCCs were harvested, mainly at 24 and $48 \mathrm{~h}$, while a constant number of PCCs showed a significant increase in their CL response compared to cells withdrawn from fish just after (10 min) they were injected with HBSS. DMSO has been used as solvent since it shows an exceptionally low toxicity. However, our data show that this substance exerts an evident inflammatory action and it is not free of secondary effect as also reported for its modulating activity on fish oestrogen receptors [33]. The effect of the Aroclor 1254 appeared to be amplificatory of the CL response at $1 \mathrm{~h}$ and $24 \mathrm{~h}$, becoming inhibitory at $48 \mathrm{~h}$ and at 1-4 weeks when the effect was more evident. Although an increased cell number was found in the peritoneal cavity following PCB injection (mainly at 24 and $48 \mathrm{~h}$ ), the above reported changes in CL activity observed by assaying a constant cell number suggest that a direct relationship between $\mathrm{CL}$ activity and total cell number cannot be drawn. On the other hand, whereas the recruitment due to H-D at $24 \mathrm{~h}$ and 1 week did not concern the relative proportion of a particular cell type, PCB injection decreased the neutrophil proportion. Such an effect was mainly observed at 1 week, when the total number of recruited cells was low and the neutrophil proportion was halved compared to H-D controls. Although we were not able to establish the role of decreased neutrophils in CL response of a whole PCC preparation, the possibility exists that the enhanced CL could be due to less numerous neutrophils provided with enhanced responsiveness. In 
this respect [21] reported that sea bass PCCs showed a CL response mainly due to neutrophil proportion in the PCC preparations [33].

However, the possibility of an increased activation capacity of macrophages cannot be excluded.

Although we do not know whether PCB treatment directly affected the phagocytic activity of peritoneal phagocytes, the activating or inhibiting effects on the CL response to zymosan suggested an immunosuppressive effect. Results also suggest that the xenobiotic mixture at the used concentrations, could maintain its inhibitory effect on innate immune system during a long time. Alterations in innate immune function upon xenobiotic exposure could result in an impaired immune defence against pathogens or inappropriate inflammatory responses producing increased tissue injury [34]. Finally, the results are in accordance with the exposure to Aroclor mixtures of isolated rat neutrophils which appeared to be activated and undergo oxidative burst through stimulation [31,35].

\section{References}

[1] Giesy JP, Kannan K. Dioxin-like and non-dioxin-like toxic effects of polychlorinated biphenyls (PCBs): implications for risk assessment. Crit Rev Toxicol 1998;28:511-69.

[2] Schmidt C. How PCBs are like grasshoppers. Environ Sci Technol 2010;44: 2752.

[3] Tolosa I, Bayona JM, Albaiges J. Spatial and temporal distribution, fluxes, and budgets of organochlorinated compounds in northwest Mediterranean sediments. Environ Sci Technol 1995;29:2519-27.

[4] Safe SH. Polychlorinated biphenyls (PCBs): environmental impact, biochemical and toxic responses, and implications for risk assessment. Crit Rev Toxicol 1994;24:87-149.

[5] Erickson MD. Analytical chemistry of PCBs. 2nd ed. Boca Raton, Fla.: CRC/Lewis Publ; 1997.

[6] Shaw GR, Connell DW. Factors controlling PCBs in food chains. In: Waid JS, editor. PCBs and the environment. Boca Raton, FL: CRC Press; 1986. p. 135.

[7] EC-SCF. Opinion of the Scientific Committee on Food on the Risk Assessment of Dioxins and Dioxin-Like PCBs in Food. Update based on new scientific information available since the adoption of SCF opinion of November 22, 2000 In: European Commission, editor. Scientific Committee on Food HaCPD-G; 2001. Brussels.

[8] Duffy N, Mc Carthy C, Zoehrer M. Environmental benchmarking for IPC industries synthesis report. In: Agency EP, editor; 2002.

[9] Schwacke LH, Zolman ES, Balmer BC, De Guise S, George RC, Hoguet J, et al. Anaemia, hypothyroidism and immune suppression associated with polychlorinated biphenyl exposure in bottlenose dolphins (Tursiops truncatus). Proc R Soc Lond [Biol] 2012;279:48-57.

[10] Jepson PD, Bennett PM, Deaville R, Allchin CR, Baker JR, Law RJ. Relationships between polychlorinated biphenyls and health status in harbor porpoises (Phocoena phocoena) stranded in the United Kingdom. Environ Toxicol Chem $2005 ; 24: 238-48$.

[11] Yoo BS, Jung KH, Hana SB, Kim HM. Apoptosis-mediated immunotoxicity of polychlorinated biphenyls (PCBs) in murine splenocytes. Toxicol Lett 1997;91: 83-9.

[12] Guardiola FA, Gónzalez-Párraga MP, Cuesta A, Meseguer J, Martínez S, Martínez-Sánchez MJ, et al. Immunotoxicological effects of inorganic arsenic on gilthead seabream (Sparus aurata L.). Aquat Toxicol 2013;134-135:112-9.

[13] Li J, Barreda DR, Zhang Y-A, Boshra H, Gelman AE, LaPatra S, et al. B lymphocytes from early vertebrates have potent phagocytic and microbicidal abilities. Nat Immunol 2006;7:1116-24.

[14] Haugland GT, Jordal AEO, Wergeland HI. Characterization of small, mononuclear blood cells from salmon having high phagocytic capacity and ability to differentiate into dendritic like cells. PLoS ONE 2012;7.
[15] Secombes CJ, Fletcher TC. The role of phagocytes in the protective mechanisms of fish. Annu Rev Fish Dis 1992:2:53-71.

[16] Secombes CJ. Macrophage activation in fish. In: Stolen J, Fletcher TC, editors. Modulators of fish immune responses. Fair Haven, NJ: SOS Publications; 1994 pp. 49-57.

[17] Allen RC, Stjernholm RL, Steele RH. Evidence for the generation of an elec tronic excitation state(s) in human polymorphonuclear leukocytes and its participation in bactericidal activity. Biochem Bioph Res Commun 1972;47: 679-84.

[18] Scott AL, Klesius PH. Chemiluminescence: a novel analysis of phagocytosis in fish. Dev Biol Stand 1980;49:14.

[19] Bols NC, Brubacher JL, Ganassin RC, Lee LE. Ecotoxicology and innate immunity in fish. Dev Comp Immunol 2001:25:853-73.

[20] Meseguer J, Esteban MA, Muñoz J, López-Ruiz A. Ultrastructure of the peritoneal exudate cells of seawater teleosts, seabream (Sparus aurata) and sea bass (Dicentrarchus labrax). Cell Tissue Res 1993;273:301-7.

[21] Vazzana M, Parrinello D, Cammarata M. Chemiluminescence response of betaglucan stimulated leukocytes isolated from different tissues and peritonea cavity of Dicentrarchus labrax. Fish Shellfish Immunol 2003;14:423-34.

[22] Afonso A, Lousada S, Silva J, Ellis AE, Silva MT. Neutrophil and macrophage responses to inflammation in the peritoneal cavity of rainbow trout Oncorhynchus mykiss. A light and electron microscopic cytochemical study. Dis Aquat Org 1998;34:27-37.

[23] Afonso A, Silva J, Lousada S, Ellis AE, Silva MT. Uptake of neutrophils and neutrophilic components by macrophages in the inflamed peritoneal cavity of rainbow trout (Oncorhynchus mykiss). Fish Shellfish Immunol 1998;8:319-38.

24] Hammond JA, Hall AJ, Dyrynda EA. Comparison of polychlorinated biphenyl (PCB) induced effects on innate immune functions in harbour and grey seals. Aquat Toxicol 2005;74:126-38.

25] Deshpande AD, Dockum BW, Cleary T, Farrington C, Wieczorek D, Bioaccumulation of polychlorinated biphenyls and organochlorine pesticides in young-of-the-year bluefish (Pomatomus saltatrix) in the vicinity of a superfund site in New Bedford Harbor, Massachusetts, and in the adjacent waters. Mar Pollut Bull 2013;72:146-64.

[26] Colombo JC, Cappelletti N, Migoya MC, Speranza E. Bioaccumulation of anthropogenic contaminants by detritivorous fish in the Río de la Plata estuary: 2-Polychlorinated biphenyls. Chemosphere 2007;69:1253-60.

[27] Miao X-S, Swenson C, Woodward LA, Li QX. Distribution of polychlorinated biphenyls in marine species from French Frigate Shoals, North Pacific Ocean. Sci Total Environ 2000;257:17-28.

[28] Iwanowicz LR, Blazer VS, McCormick SD, VanVeld PA, Ottinger CA Aroclo 1248 exposure leads to immunomodulation, decreased disease resistance and endocrine disruption in the brown bullhead, Ameiurus nebulosus. Aquat Toxicol 2009;93:70-82.

[29] Smits JE, Fernie KJ, Bortolotti GR, Marchant TA. Thyroid hormone suppression and cell-mediated immunomodulation in american kestrels (Falco sparverius) exposed to PCBs. Arch Environ Contam Toxicol 2002;43:338-44.

[30] Mckinney JD, Waller CL. Polychlorinated-biphenyls as hormonally active structural analogs. Environ Health Perspect 1994;102:290-7.

[31] Ganey PE, Sirois JE, Denison M, Robinson JP, Roth RA. Neutrophil function after exposure to polychlorinated-biphenyls in-vitro. Environ Health Perspect 1993;101:430-4.

[32] Lacroix A, Fournier M, Lebeuf M, Nagler JJ, Cyr DG. Phagocytic response of macrophages from the pronephros of American plaice (Hipoglossoides platessoides) exposed to contaminated sediments from Baie des Anglais, Quebec. Chemosphere 2001;45:599-607.

[33] Mortensen AS, Tolfsen CC, Arukwe A. Gene expression patterns in estrogen (nonylphenol) and aryl hydrocarbon receptor agonists (PCB-77) interaction using rainbow trout (Oncorhynchus Mykiss) primary hepatocyte culture. J Toxicol Environ Health A 2006;69:1-19.

[34] Tuomala M, Hirvonen MR, Holopainen M, Savolainen K. Stimulation of human polymorphonuclear leukocytes by consecutive doses of quartz and interactions of quartz with fMLP. Toxicol Appl Pharmacol 1993;118:224-32.

[35] Brown AP, Ganey PE. Neutrophil degranulation and superoxide production induced by polychlorinated-biphenyls are calcium-dependent. Toxicol Appl Pharmacol 1995:131:198-205. 